\title{
The transformation of Saperda calcarata (Coleoptera: Cerambycidae) into a cellulose digester through the inclusion of fungal enzymes in its diet
}

\author{
Jerome J. Kukor* and Michael M. Martin \\ Division of Biological Sciences, University of Michigan, Ann Arbor, MI 48109-1048, USA
}

\begin{abstract}
Summary. The larvae of the aspen borer, Saperda calcarata, which feed on the inner bark and sapwood of living aspen stems, are unable to digest cellulose. However, they can be transformed into cellulose digesters by adding the active cellulase complex of the fungus, Penicillium funiculosum, to their diet. $S$. calcarata larvae are preadapted to exploit the digestive potential of ingested microbial enzymes. We argue that ingested fungal enzymes may be responsible for cellulose digestion in many, perhaps most or even all, cellulose digesting cerambycid beetles.
\end{abstract}

Key words: Saperda calcarata - Cerambycidae - Cellulose digestion - Cellulase - Acquired digestive enzymes

The ability to digest cellulose is common among the woodboring larvae of anobiid and cerambycid beetles (Martin 1983). At one time it was believed that intracellular symbionts might play a role in cellulose digestion in these insects (Buchner 1928; Uvarov 1929). However, that possibility was conclusively ruled out when it was demonstrated that cellulose is digested as efficiently by symbiont-free species as by symbiont-containing species (Ripper 1930; Mansour and Mansour-Bek 1934a, b; Müller 1934) and that the symbionts, which are yeasts, are not cellulolytic (Müller 1934). After it was recognized that cellulose digestion was not dependent upon endosymbionts, it was concluded that anobiid and cerambycid beetles must be able to produce their own cellulolytic enzymes. It is important to recognize, however, that this conclusion was arrived at by default, not because of compelling evidence in its favor.

Recently we have shown that the ability of the balsam fir sawyer, Monochamus marmorator (Cerambycidae), to digest cellulose is not due to enzymes produced by the beetles, but rather to fungal enzymes ingested by the larvae during the consumption of fungus-infected wood (Kukor and Martin 1986a). We also proposed that this mechanism for cellulose digestion might be widespread among xylophagous beetle larvae, and that there was actually no evidence that any anobiid or cerambycid species produced its own cellulase complex.

\footnotetext{
* Present address and address for offprint requests: Department of Microbiology and Immunology, University of Michigan Medical School, M-5605/0620, 1301 E. Catherine St., Ann Arbor, MI 48109 0620 USA
}

In this study we have investigated polysaccharide digestion in the larvae of another cerambycid, the aspen borer, Saperda calcarata. Species of the genus Saperda do not attack the decayed wood of dead trees. The females oviposit in slits chewed in the bark of live trees, and the larvae move into the inner bark and sapwood to feed. Thus, $S a-$ perda larvae rarely encounter or consume fungus-infected wood, precluding a reliance upon ingested microbial enzymes for the digestion of polysaccharides. If our interpretation of the origins of cellulolytic capacity in the cerambycids is correct, we would not expect $S$. calcarata to be able to digest cellulose.

Our research on S. calcarata is part of an ongoing series of investigations of the role of acquired fungal enzymes in the digestive processes and nutritional ecology of woodand detritus-feeding arthropods (Martin and Martin 1978, 1979; Sharma et al. 1984; Kukor and Martin 1983, 1986a, b).

\section{Methods and materials \\ Collection and maintenance of animals}

$S$. calcarata larvae were collected from stems and large branches of trembling aspen, Populus tremuloides, at the University of Michigan Biological Station, Emmet County, Michigan. Since $S$. calcarata cannot be maintained for extended periods on artificial laboratory diets, larvae were kept in 50-cm long aspen branch sections with paraffinsealed ends. Larvae could be kept in this way for 2-3 weeks under laboratory conditions.

\section{Extract preparation and enzyme assays}

Midguts were dissected from $S$. calcarata larvae as described by Martin et al. (1980). Since the $\mathrm{pH}$ of the midgut fluid ranges between 7.05 and 7.20 , extracts were prepared in $100 \mathrm{mM}$ Tris- $\mathrm{HCl}$ buffer (tris[hydroxymethyl]aminomethane), $\mathrm{pH}$ 7.1. For enzyme assays, the pooled midguts from 8-10 larvae were prepared as described in Martin et al. (1981).

Activities toward potato amylose (Calbiochem), carboxymethylcellulose (CMC) (Sigma), laminarin (United States Biochemical), citrus pectin (Sigma), larchwood xylan (United States Biochemical), microcrystalline cellulose (Polyscience), and chitin (Sigma) were assayed by measuring 
the liberation of reducing groups (maltose equivalents) using the 3,5-dinitrosalicylic acid reagent of Bernfeld (1955).

\section{Culturing larvae on a cellulase-amended diet}

A cellulase-amended diet for $S$. calcarata was prepared by stirring 6 grams of freshly prepared shavings of aspen sapwood and inner bark in $200 \mathrm{ml}$ of a solution of Penicillium funiculosum cellulase (Sigma) $\left(500\right.$ units/ml) for $1 \mathrm{~h}$ at $4^{\circ} \mathrm{C}$. The wood shavings were collected by centrifugation, blotted dry, and lyophilized. A control diet was prepared in similar fashion by soaking aspen wood shavings in a solution of heat-inactivated $P$. funiculosum cellulase. Weighed portions of the lyophilized diets were extracted and assayed for activity towards microcrystalline cellulose, as described by Kukor and Martin (1986a).

Approximately $700 \mathrm{mg}$ of diet was placed in individual capped plastic cups ( $2.5 \mathrm{~cm}$ diameter), the bottom of which contained a thin layer of $2 \%$ agar. The lyophilized diet was allowed to rehydrate for several hours before larvae were placed in the cups. Four larvae were placed in cups containing cellulase-active diet, and 4 were placed in cups containing cellulase-inactive diet. After 3 days, one larva from each treatment was sacrificed and its midgut dissected, extracted, and assayed for activity toward microcrystalline cellulose. The remaining 3 larvae from each group were used immediately for determining ${ }^{14} \mathrm{C}$-cellulose utilization.

\section{${ }^{14} \mathrm{C}$-Cellulose utilization}

${ }^{14} \mathrm{C}$-Cellulose utilization was measured using the protocol of Kukor and Martin (1986a), except that the food tablets were made of milled aspen inner bark and sapwood (Wiley mill, 40-mesh), amended with $5 \%$ (wt/wt) $\left[\mathrm{U}^{14}{ }^{14} \mathrm{C}\right]$ cellulose (ICN).

\section{Results}

The enzymatic activity of $S$. calcarata gut fluid toward various polysaccharides

The gut fluid of $S$. calcarata larvae is active toward potato amylose, citrus pectin, larchwood xylan, and laminarin (Table 1), indicating that the larvae are equipped to digest starch, pectin, hemicelluloses with an arabino-4-O-methylglucuronoxylan structure, and polysaccharides, such as callose, containing $\beta$-1,3-linked glucose units. No activity could be detected toward chitin. The gut fluid is also active toward carboxymethylcellulose, indicating the presence of endoglucanases $\left(\mathrm{C}_{\mathrm{x}}\right.$-cellulases) which attack soluble degradation products of cellulose or amorphous regions of the predominantly crystalline structure of native cellulose. Activity toward carboxymethylcellulose is not necessarily indicative of an ability to digest cellulose, however, since the degradation of native cellulose requires the synergistic action of a complex of enzymes (Ljungdahl and Erikkson 1985). Enzymatic activity toward microcrystalline cellulose is barely detectable in the digestive fluids of $S$. calcarata larvae, indicating that these animals do not possess a complete cellulase complex. The inability of $S$. calcarata larvae, collected from their natural galleries, to digest cellulose was confirmed by demonstrating that no ${ }^{14} \mathrm{C}$ was detectable in the respiratory carbon dioxide produced by larvae that had ingested $\left[\mathrm{U}_{-}{ }^{14} \mathrm{C}\right]$-cellulose (Table 2).

The inability of $S$. calcarata larvae to digest cellulose and the absence of enzymatic activity toward microcrystalline cellulose in the gut fluid are entirely consistent with our suggestion that cellulose digestion by cerambycid larvae is a capacity acquired by the ingestion of active fungal enzymes.

Low levels of cellulolytic activity have been reported

Table 1. Enzymatic activity toward various polysaccharides of extracts of midguts from $S$. calcarata larvae collected from natural galleries or fed aspen wood chips amended with Penicillium funiculosum cellulase, and of extracts of aspen wood amended with $P$. funiculosum cellulase. Each value is the mean \pm standard error of the mean for the number of replicates in parenthesis. $N D$ not determined

Source of extract

Units of activity ${ }^{\mathrm{a}} / \mathrm{mg}$ (dry weight) of dissolved solids in extract

$\begin{array}{ll}\text { Amylose Pectin Xylan Laminarin } & \begin{array}{l}\text { Carboxymethyl- } \\ \text { cellulose }\end{array} \\ \begin{array}{l}\text { Microcrystalline } \\ \text { cellulose }\end{array}\end{array}$

Midguts of S. calcarata

Collected from natural galleries in aspen

$\begin{array}{llllll}2.62 \pm 0.03 & 3.60 \pm 0.01 & 1.93 \pm 0.06 & 2.04 \pm 0.01 & 1.56 \pm 0.02 & 0.02 \pm 0.003 \\ (3) & (3) & (3) & (3) & (3) & (3) \\ \text { ND } & \text { ND } & \text { ND } & \text { ND } & \text { ND } & \begin{array}{l}0.39 \\ (1)\end{array} \\ & & & & & \\ \text { ND } & \text { ND } & \text { ND } & \text { ND } & \text { ND } & \begin{array}{l}0.06 \\ (1)\end{array} \\ & & & & & \\ & & & & & \\ \text { ND } & \text { ND } & \text { ND } & \text { ND } & \text { ND } & 3.15 \pm 0.2 \\ & & & & & (3) \\ \text { ND } & \text { ND } & \text { ND } & \text { ND } & \text { ND } & 0.0 \pm 0.0 \\ & & & & & (3)\end{array}$

Cultured for 3 days on aspen wood chips plus cellulase (immediately prior to transfer to aspen wood amended with labeled cellulose)

Cultured for 3 days on aspen wood chips plus heat-inactivated cellulase (immediately prior to transfer to aspen wood amended with labeled cellulose)

Aspen wood chips

Amended with $P$. funiculosum cellulase

\begin{tabular}{llllll}
$2.62 \pm 0.03$ & $3.60 \pm 0.01$ & $1.93 \pm 0.06$ & $2.04 \pm 0.01$ & $1.56 \pm 0.02$ & $0.02 \pm 0.003$ \\
$(3)$ & $(3)$ & $(3)$ & $(3)$ & $(3)$ & $(3)$ \\
ND & ND & ND & ND & ND & $\begin{array}{l}0.39 \\
(1)\end{array}$ \\
& & & & & \\
ND & ND & ND & ND & ND & $\begin{array}{l}0.06 \\
(1)\end{array}$ \\
& & & & & \\
& & & & & \\
ND & ND & ND & ND & ND & $3.15 \pm 0.2$ \\
& & & & & $(3)$ \\
ND & ND & ND & ND & ND & $0.0 \pm 0.0$ \\
& & & & & $(3)$ \\
\hline
\end{tabular}

Amended with heat inactivated $P$. funiculosum cellulase

a A unit of activity is the amount of enzyme required to liberate 1 micromole of maltose equivalents per hour under the conditions of the assay $\left(37^{\circ} \mathrm{C}, \mathrm{pH} 7.1\right.$, incubation volume $\left.1.0 \mathrm{ml}\right)$ 
Table 2. Utilization of $\left[\mathrm{U}^{14} \mathrm{C}\right]$-cellulose by $S$. calcarata larvae. The duration of the experiment was 24 hours. Each value is the mean \pm the standard error of the mean for three replicates

\begin{tabular}{ll}
$\begin{array}{l}\text { Treatment prior to transfer to } \\
{ }^{14} \mathrm{C} \text {-cellulose-containing diet }\end{array}$ & $\begin{array}{l}\text { Percent of label } \\
\text { from }{ }^{14} \mathrm{C} \text {-cellulose } \\
\text { in diet released as }{ }^{14} \mathrm{CO}_{2}\end{array}$ \\
\hline $\begin{array}{l}\text { Collected from natural galleries } \\
\text { in aspen }\end{array}$ & $0.0 \pm 0.0$ \\
$\begin{array}{l}\text { Cultured for } 3 \text { days on aspen wood } \\
\text { chips plus } P \text {. funiculosum cellulase }\end{array}$ & $1.3 \pm 0.2$ \\
$\begin{array}{l}\text { Cultured for } 3 \text { days on aspen wood } \\
\text { chips plus heat-inactivated }\end{array}$ & $0.03 \pm 0.02$ \\
$P$. funiculosum cellulase &
\end{tabular}

in the gut fluids of $S$. populnea, a European species with feeding habits very similar to those of $S$. calcarata (Schlottke 1945). Schlottke also reported that cellulase activity in the gut fluid was lower, and amylase activity higher, in this species than in other species of cerambycids with diets of dead or decayed wood. In assaying for cellulase, Schlottke used a ten-day incubation time, and detected cellulase activity in the Malpighian tubules and the hemolymph, neither of which are plausible sources for the digestive enzymes of insects. Schlottke, aware of the enigma posed by cellulases from these two sources, hypothesized that the observed activity might not be due to digestive cellulases, but rather to chitinases that normally function during molting, but which also possess some activity toward other $\beta$-1,4-glucans, such as cellulose. Whether or not Schlottke's explanation is correct, we believe that there is sufficient ambiguity in his result that it cannot be accepted as a convincing demonstration of cellulolytic capacity in S. populnea larvae.

The acquisition of cellulolytic capacity by $S$. calcarata larvae on a diet containing fungal cellulase

Although $S$. calcarata larvae do not normally ingest fungal enzymes, there seemed to be no reason a priori to expect that such enzymes would be any less stable or active in the gut fluid of this species than in $M$. marmorator. We, therefore, undertook experiments to determine whether $S$. calcarata larvae could acquire cellulolytic capacity by ingesting a food that contained fungal cellulase.

Larvae were cultured on aspen wood shavings that had been impregnated with the cellulase complex of the fungus, Penicillium funiculosum. Although the larvae did not consume large amounts of wood when it was presented to them in this unnatural form, they did feed at a reduced rate, and after three days their gut fluids exhibited significant activity toward microcrystalline cellulose (Table 1). No cellulase activity was detectable in the gut fluids of larvae that had fed on aspen wood shavings to which heat-inactivated fungal cellulase had been added.

Larvae with ingested fungal cellulase in their gut fluids are able to digest $\left[\mathrm{U}-^{14} \mathrm{C}\right]$-cellulose (Table 2). Labeled cellulose was incorporated into the diet of the larvae by feeding them aspen wood shavings amended with ${ }^{14} \mathrm{C}$-cellulose fiber, and cellulose digestion was monitored by counting the ${ }^{14} \mathrm{C}$ in the respiratory carbon dioxide produced by the larvae. In these experiments it was not possible to achieve a clean separation of frass and uneaten food. As a consequence, it was not possible to obtain an accurate measure of the amount of food or labelled cellulose actually ingested, and we had to settle for a determination of the fraction of ${ }^{14} \mathrm{C}$ presented to the larvae in their food that was released in the form of carbon dioxide. Since the larvae did not consume very much of the ${ }^{1.4} \mathrm{C}$-cellulose-amended aspen shavings during this experiment, the value we obtained, $1.3 \%$, grossly underestimates the efficiency with which the larvae assimilated the cellulose actually ingested.

\section{Conclusions}

Ingested fungal enzymes have been shown to be responsible for cellulose digestion in the termite, Macrotermes natalensis (Martin and Martin 1978, 1979), the siricid woodwasp, Sirex cyaneus (Kukor and Martin 1983), and the cerambycid beetle, Monochamus marmorator (Kukor and Martin 1986a). Although $S$. calcarata larvae do not normally digest cellulose, they are transformed into cellulose digesters when their diet contains active fungal cellulases. The larvae are preadapted for the exploitation of ingested enzymes.

The conditions which prevail in the gut fluids of cerambycid larvae are quite compatible with a role for ingested fungal enzymes. The $\mathrm{pH}$ of the gut fluid is close to neutrality, generally ranging between 6.8 and 7.2 (Swingle 1931; Schlottke 1945; Grayson 1958; Mishra and Singh 1978). Although this range is slightly above the $\mathrm{pH}$ at which most fungal cellulases manifest their maximum activity, it is nonetheless a range in which such enzymes are stable and exhibit significant activity. The proteolytic enzymes of cerambycid gut fluid have not been thoroughly studied. Schlottke (1945) detected proteolytic activity in the gut fluids of several species, and noted that activity was not evenly distributed in the midgut.Activity was quite low in the anterior portion of the midgut, which is the region where cellulase activity is generally highest, and was higher in the posterior portion where cellulase activity is lower. $\mathrm{He}$ also noted that the anterior portion of the midgut is slightly acidic while the posterior portion is slightly alkaline, and that the proteases are more active under alkaline than acidic conditions. These results all point to the conclusion that ingested enzymes would probably not be subject to rapid digestion in the midgut fluids. The anterior portion of the midgut in particular would seem to be a region of the alimentary tract in which ingested fungal cellulases would be stable and active.

We predict that ingested fungal enzymes will prove to be responsible for cellulose digestion in many, perhaps most or even all, cellulose-digesting cerambycid beetles. We also maintain that there is no longer any justification for believing that the larvae of any cerambycid species are able to secrete all of the enzymes required for cellulose digestion. To be sure, many additional species must be examined before these sweeping generalizations can be accepted as anything more than provocative challenges. We hope the challenges will be accepted, and the generality of the importance of ingested enzymes in the nutritional ecology of woodfeeding beetles can be established.

Acknowledgements. This research was supported by NSF grant PCM-82-03537 to M.M. Martin. We thank the staff of the University of Michigan Biological Station for technical support and for permission to use their facilities. 


\section{References}

Bernfeld $\mathrm{P}$ (1955) Amylases, $\alpha$ and $\beta$. In: Colowick SP, Kaplan NO (eds) Methods in enzymology, vol 1. Academic Press, New York, pp 149-150

Buchner P (1928) Holznahrung und Symbiose. Springer Verlag, Berlin Heidelberg New York

Grayson JM (1958) Digestive tract $\mathrm{pH}$ of six species of Coleoptera. Ann Entomol Soc Am 51:403-405

Kukor JJ, Martin MM (1983) Acquisition of digestive enzymes by siricid woodwasps from their fungal symbiont. Science 220:1161-1163

Kukor JJ, Martin MM (1986a) Cellulose digestion in Monochamus marmorator Kby. (Coleoptera: Cerambycidae): role of acquired fungal enzymes. J Chem Ecol 12:1057-1070

Kukor JJ, Martin MM (1986b) The effect of acquired microbial enzymes on assimilation efficiency in the common woodlouse, Tracheoniscus rathkei. Oecologia (Berlin) 69:360-366

Ljungdahl LG, Eriksson KE (1985) Ecology of microbial cellulose degradation. Adv Microb Eco1 8:237-299

Mansour K, Mansour-Bek JJ (1934a) On the digestion of wood by insects. J Exp Biol $11: 243-256$

Mansour K, Mansour-Bek JJ (1934b) The digestion of wood by insects and the supposed role of microorganisms. Biol Rev $9: 363-382$

Martin MM (1983) Cellulose digestion in insects. Comp Biochem Physiol 75A:313-324

Martin MM, Martin JS (1978) Cellulose digestion in the midgut of the fungus-growing termite Macrotermes natalensis: the role of acquired fungal enzymes. Science 199:1453-1455
Martin MM, Martin JS (1979) The distribution and origins of the cellulolytic enzymes of the higher termite Macrotermes natalensis. Physiol Zool 52:1-11

Martin MM, Martin JS, Kukor JJ, Merritt RW (1980) The digestion of protein and carbohydrate by the stream detritivore, Tipula abdominalis (Diptera: Tipulidae). Oecologia (Berlin) 46:360-364

Martin MM, Kukor JJ, Martin JS, O'Toole TE, Johnson MW (1981) Digestive enzymes of fungus-feeding beetles. Physiol Zool 54:137-145

Mishra SC, Singh P (1978) Polysaccharide digestive enzymes in the larvae of Stromatium barbatum (Fabr.), a dry wood borer (Coleoptera: Cerambycidae). Mater Org 13:115-122

Müller W (1934) Untersuchungen über die Symbiose von Tieren mit Pilzen und Bakterien. Arch Mikrobiol 5:84-147

Ripper W (1930) Zur Frage des Celluloseabbaus bei der Holzverdauung xylophager Insektenlarven. Z Vgl Physiol 13:314-333

Schlottke E (1945) Über die Verdauungsfermente im Holzfressender Käferlarven. Zool Jb, Allg Zool Physiol Tiere 61:88-140

Sharma BR, Martin MM, Shafer JA (1984) Alkaline proteases from the gut fluids of detritus-feeding larvae of the crane fly, Tipula abdominalis (Say) (Diptera, Tipulidae). Insect Biochem $14: 37-44$

Swingle MC (1931) Hydrogen-ion concentrations within the digestive tract of certain insects. Ann Entomol Soc Am 24:489-495

Uvarov BP (1929) Insect nutrition and metabolism. Trans Entomol Soc Lond $76: 255-343$

Received May 5, 1986 